\title{
PRODUCTION AND USE OF MUTANASE FROM TRICHODERMA HARZIANUM FOR EFFECTIVE DEGRADATION OF STREPTOCOCCAL MUTANS
}

\author{
Adrian Wiater; Janusz Szczodrak*; Malgorzata Pleszczyńska; Katarzyna Próchniak \\ Department of Industrial Microbiology, Maria Curie-Sklodowska University, Lublin, Poland.
}

Submitted: December 09, 2004; Approved: April 26, 2005

\begin{abstract}
Basic cultural parameters affecting mutanase production by Trichoderma harzianum F-340 in shaken flasks and aerated fermenter cultures have been standardized. The best medium for enzyme production was Mandels medium A with initial $\mathrm{pH} 5.3$, supplemented with $0.3 \%$ mutan and $0.05 \%$ peptone and inoculated with $20 \%$ of the 72 -h mycelium as inoculum. It was shown that mycelial mass, used in the culture medium as a sole carbon source, induced mutanase synthesis and could be utilized as an inexpensive and easily available substitute for bacterial mutan. Application of optimized medium and cultural conditions enabled us to obtain a high mutanase yield $(0.6-0.7 \mathrm{U} / \mathrm{mL}, 2.0-2.5 \mathrm{U} / \mathrm{mg}$ protein) in a short period of time (35 days), which was much higher than the best reported in literature. The enzyme in crude state was stable in the $\mathrm{pH}$ range of $4.5-6.0$, and at temperatures of up to $40^{\circ} \mathrm{C}$; its maximum activity was recorded at $45^{\circ} \mathrm{C}$ and at $\mathrm{pH} 5.5$. The mutanase preparation obtained from the $T$. harzianum fungus was relatively stable under storage conditions, and showed a high hydrolytic potential in reaction with a mixed-linkage $(\alpha-1,3$, $\alpha-1,6)$ water-insoluble mutan of streptococcal origin (hydrolysis yield reached a value of $69 \%$ in $24 \mathrm{~h}$ ). Steady-state measurement of the enzymic reaction products during the hydrolysis revealed that mutanase exhibited an exo type of action on mutan. Thin-layer chromatographic analysis showed that glucose was the primary final product of mutan hydrolysis with mutanase. The potential application of mutanase in dentistry is discussed.
\end{abstract}

Key words: Trichoderma harzianum, mutanase, mutan

\section{INTRODUCTION}

Mutans, synthesized from dietary sucrose by glucosyltransferases of cariogenic streptococci, are a major virulence factor for dental caries induction in humans and experimental animals (14). These water-insoluble and adherent glucans possess a highly branched structure with a majority of $\alpha-1,3$ and a minority of $\alpha-1,6$ glycosidic bonds. The abundance of $\alpha-1,3$ linkages is associated with water insolubility while the presence of $\alpha-1,6$-linked side chains contributes to the adhesive properties of these biopolymers (32). Mutans act as a framework for dental plaque, where they mediate attachment of bacteria to the tooth surface and to other bacteria, thus stabilizing the plaque biofilm (18). Accordingly, strategies to reduce the disease potential of dental plaque have included the possibility of using mutan-degrading enzymes to disrupt the molecular architecture of plaque. Some of these enzymes, termed mutanases $(\alpha-1,3-$ glucan 3-glucanohydrolases), have shown high potential as caries preventive agents because they degrade water-insoluble glucans present in dental plaque $(11,31,35)$. However, the use of mutanases in caries prophylaxis has had little commercial success due to the unavailability of enzymic preparations acceptable for oral applications.

Mutanases from various bacteria and filamentous fungi have been investigated; yet, in most cases, the enzyme activity is relatively low, and cultural conditions for mutanase production have not been thoroughly established $(9,10,19)$. Also, search for additional mutanase producers among wild-type fungi is

*Corresponding Author. Mailing address: Department of Industrial Microbiology, Maria Curie-Sklodowska University, Akademicka 19, 20-033 Lublin, Poland. Tel.: (+4881) 537-5909. Fax: (+4881) 537-5959. E-mail: szczo@biotop.umcs.lublin.pl 
necessary to find new potential sources with different characteristics. Moreover, bacterial synthesis of mutan for the specific induction and extracellular secretion of mutanase in microbial cultures has not been realized on a larger scale, and this type of water-insoluble exopolysaccharide is not yet available as a commercial product. Therefore, identification of alternative and inexpensive carbon sources as mutanase inducers would facilitate the enzyme production on a larger scale, and at relatively low costs.

As for the enzymatic hydrolysis of mutans, several papers deal with action patterns of some exo- and endoglucanases $(1,9)$. Mutanases from different sources exhibit diverse action patterns, but fundamentally they degrade mutan to glucose. In the enzymic conversion of mutan, it is essential to obtain a high sugar yield per enzyme unit. Thus, optimized conditions of mutan hydrolysis play a significant role in the economy of the degradation process.

The objective of these investigations was to find the best operating conditions for efficient production of fungal mutanase in shaken flasks and fermenter cultures and to search for alternative inducers of enzyme synthesis as well as to determine some of mutanase properties. The aim was also to effectively hydrolyze mutan by fungal mutanase, to examine the mode of enzyme action towards mutan, and to identify the final degradation products.

\section{MATERIALS AND METHODS}

\section{Fungal strain, media and growth conditions}

Stock cultures of Trichoderma harzianum F-340 (Czech Collection of Microorganisms, Brno, Czech Republic), maintained at $4^{\circ} \mathrm{C}\left( \pm 2^{\circ} \mathrm{C}\right)$ on potato dextrose agar slants, were used for inoculations. The liquid mineral medium $\mathrm{A}$ ( $\mathrm{pH}$ 5.3), as described by Mandels et al. (16), supported by $0.5 \%$ mutan, $0.1 \%$ peptone proteose, and $0.1 \%$ Tween 80 was used for mutanase production. This medium was optimized during

Table 1. Effect of different mineral media on mutanase production by $T$. harzianum in shaken flask cultures.

\begin{tabular}{|c|c|c|c|}
\hline \multirow{2}{*}{ Medium $^{\mathrm{a}}$} & \multirow{2}{*}{ Days $^{\mathrm{b}}$} & \multicolumn{2}{|c|}{ Mutanase activity } \\
\hline & & $(\mathrm{U} / \mathrm{mL})$ & $\begin{array}{l}\mathrm{U} / \mathrm{mg} \\
\text { protein }\end{array}$ \\
\hline Mandels et al. (16) - medium C & 7 & 0.301 & 1.316 \\
\hline Mandels et al. (16) - medium $A^{c}$ & 4 & 0.651 & 2.170 \\
\hline Saunders et al. (25) & 2 & 0.070 & 0.262 \\
\hline Szczodrak et al. (30) & 2 & 0.208 & 0.629 \\
\hline
\end{tabular}

${ }^{\mathrm{a} A l l}$ media (pH 5.3) were supported by $0.5 \%$ mutan; ${ }^{\mathrm{b}}$ Incubation period for maximum activity; ${ }^{\mathrm{C}}$ The same as $\mathrm{C}$ but with the addition of peptone proteose $(0.1 \%)$. experiments with respect to carbon source, peptone concentration, initial $\mathrm{pH}$, and medium volume. The media listed in Table 1 were also studied. Shake cultures were conducted in $500 \mathrm{~mL}$ conical flasks containing $100 \mathrm{~mL}$ of sterile medium. Unless otherwise stated, the flasks were seeded with conidia to a final concentration of about $2 \times 10^{5}$ conidia/mL and placed on an orbital rotary shaker at $220 \mathrm{rpm}$ and $30^{\circ} \mathrm{C}$ for 4 days.

For enzyme production on a larger scale, the strain was grown in an optimized Mandels medium in $1.8 \mathrm{~L}$ batches in a 2.5 L glass fermenter (Biostat B, B. Braun Biotech International $\mathrm{GmbH}$, Germany). The medium was autoclaved for $20 \mathrm{~min}$ at $121^{\circ} \mathrm{C}$ and inoculated with $20 \%(\mathrm{v} / \mathrm{v})$ of the $72 \mathrm{~h}$ mycelium of $T$. harzianum grown in shaken flasks in the same medium but with $0.5 \%$ glucose as the sole carbon source. The fermenter culture was run at $30^{\circ} \mathrm{C}$ for 7 days at the aeration rate of $1 \mathrm{~L}$ air/ $1 \mathrm{~L}$ medium/min and with stirrer speed of $300 \mathrm{rpm}$. The $\mathrm{pH}$ was not regulated. Antifoam B emulsion (Sigma-Aldrich, St. Louis, MO, USA) was used for breaking the foam. The mycelium from flasks and fermenter cultures was separated by centrifugation ( $20 \mathrm{~min}$ at $6,000 \mathrm{xg}$ ) and the clarified supernatant was used as an enzyme solution for various tests, or it was lyophilized in a freeze-dryer (Labconco, USA). Dry powder with a mutanase activity of 0.026 $\mathrm{U} / \mathrm{mg}$, protein content of $0.033 \mathrm{mg} / \mathrm{mg}$ lyophilizate, and trace activity of protease was used as an enzyme preparation for determination of mutanase properties and mutan hydrolysis.

\section{Assays}

The standard mutanase assay mixture contained $0.5 \mathrm{~mL}$ of $0.4 \%$ mutan in $0.2 \mathrm{M}$ sodium acetate buffer $(\mathrm{pH} 5.5)$ and $0.5 \mathrm{~mL}$ of the suitably diluted enzyme solution. After $1 \mathrm{~h}$ incubation at $40^{\circ} \mathrm{C}$, the released reducing sugars were quantified by SomogyiNelson's method $(20,28)$. Appropriate substrate and enzyme blanks were included to correct for any free reducing group not emanating from the mutan. One unit of mutanase activity (U) was defined as the amount of enzyme hydrolyzing mutan to yield reducing sugars equivalent to $1 \mu \mathrm{mol}$ of glucose $/ \mathrm{min}$, and expressed as units per $\mathrm{mL}$ of culture $(\mathrm{U} / \mathrm{mL})$. Specific activity was defined as mutanase units per mg of protein (U/mg protein), $1 \mathrm{U}$ corresponds to $16.67 \mathrm{nkat}$. To isolate intracellular mutanase, the washed mycelium was disrupted using a mortar and pestle for $10 \mathrm{~min}$ at $4^{\circ} \mathrm{C}$ with equal weight of corundum $\mathrm{A}-320$ and four volumes of acetate buffer ( $\mathrm{pH}$ 5.5). The homogenate was centrifuged at 17,500 $\mathrm{x}$ g for $20 \mathrm{~min}$, and the supernatant fluid served as a cell-free extract for estimation of enzymic activity.

The activities of all the accompanying hydrolytic enzymes present in mutanase preparation, such as dextranase, laminarinase, pullulanase, amylase, invertase, chitinase and protease were quantified under the optimized reaction conditions by measuring the reducing sugars, $\mathrm{N}$-acetylglucosamine or diazotized aromatic amino acids released by these enzymes from the respective carbohydrates or azocasein $(2,7,23,30)$. One microgram of reducing sugars or N-acetyl- 
glucosamine formed per min was taken as the unit of enzymic activity. The reducing power was analyzed by the SomogyiNelson's method. In the case of protease, an absorption change of 0.1 in the reaction mixture under the reaction conditions was taken as an activity unit.

Glucose was measured enzymically using glucose oxidaseperoxidase reagent (15). Protein concentration was measured by the method of Schacterle and Pollack (26) using crystalline bovine serum albumin as a standard.

The influence of $\mathrm{pH}$ on mutanase activity was examined in a standard assay mixture, except that $0.2 \mathrm{M}$ phosphate-citrate (McIlvaine) buffers (pH 3.0-8.0) were used instead of acetate buffer. The $\mathrm{pH}$ stability was determined in a similar way, apart from the fact that after preincubation of the enzyme solution at various $\mathrm{pH}$ values and at $40^{\circ} \mathrm{C}$ for $24 \mathrm{~h}$, aliquots were removed, and the remaining activities were assayed by the standard method at the optimum $\mathrm{pH}$ of 5.5. The effect of temperature on the enzyme activity was estimated in a standard assay mixture containing acetate buffer, but the reaction temperature was changed gradually from 20 to $60^{\circ} \mathrm{C}$ and the activity was measured at the optimum $\mathrm{pH}$ value. Thermal stability was measured in the same way as temperature optimization. The enzyme solution was incubated without mutan at different temperatures for $1 \mathrm{~h}$ under the optimum $\mathrm{pH}$ conditions. Then it was cooled, and the residual activity was assayed by the standard method at the optimum $\mathrm{pH}$ of 5.5 and the temperature of $45^{\circ} \mathrm{C}$. The relative activity at each $\mathrm{pH}$ and temperature was expressed as a percentage of the maximum activity.

Submerged cultures were performed in triplicate, and analyses were carried out at least in duplicate. The values given here are means of all the independent measurements. Mean standard error of the mutanase estimate was $\pm 8.2 \times 10^{-3} \mathrm{U}$ and ranged from $\pm 7.5 \times 10^{-5}$ to $\pm 1.9 \times 10^{-2}$. Mean standard error in protein determination was $\pm 4.3 \times 10^{-3} \mathrm{mg}$ and ranged from \pm 5.2 $\times 10^{-5}$ to $\pm 8.6 \times 10^{-3}$. Other methodological details are given in tables and figures.

\section{Preparation of mutan}

Mutan was synthesized from sucrose with the use of a mixture of crude glucosyltransferases of cariogenic Streptococcus sobrinus 21020 (OMZ 176, provided by the Culture Collection, University of Göteborg, Sweden), as reported previously (34). The linkage structure of natural mutan, determined by ${ }^{1} \mathrm{H}$ nuclear magnetic resonance (NMR), turned out to be a mixed-linkage $(\alpha-1,3),(\alpha-1,6)$ polymer with a greater proportion of $\alpha-1,3$ to $\alpha-1,6$ linkages (79.8 and $20.2 \%$, respectively).

The ${ }^{1} \mathrm{H}$ NMR spectra of water-insoluble mutan preparation were recorded with the Avance ( $300 \mathrm{MHz}$ ) spectrometer (Bruker BioSpin GmbH, Rheinstetten/Karlsruhe, Germany) at $60^{\circ} \mathrm{C}$. ${ }^{1} \mathrm{H}$ chemical shift values were estimated using acetone $\left(\delta_{\mathrm{H}}-\right.$ $2.225 \mathrm{ppm})$ as the internal standard. Glucan $(20 \mathrm{mg})$ was dissolved in $0.6 \mathrm{~mL}$ of $30 \% \mathrm{NaOD}$ in $\mathrm{D}_{2} \mathrm{O}$. The percentage of $\alpha-1,3-$ and $\alpha-1,6$-glucosidic linkages was calculated from the surface areas of anomeric signals.

\section{Hydrolysis of mutan by mutanase and identification of degradation products}

Digestion of mutan was performed in plugged conical flasks $(100 \mathrm{~mL})$ with $0.05 \%$ sodium azide as a preservative. The reaction mixture $(50 \mathrm{~mL})$ contained $50 \mathrm{mg}$ of mutan and $0.195 \mathrm{U} / \mathrm{mg}$ substrate of mutanase preparation in $0.2 \mathrm{M}$ sodium acetate buffer ( $\mathrm{pH}$ 5.5). The flasks were incubated for $48 \mathrm{~h}$ at $45^{\circ} \mathrm{C}$ in a water bath shaker agitated at $150 \mathrm{rpm}$. Samples were withdrawn at various intervals of up to $48 \mathrm{~h}$, heated at about $100^{\circ} \mathrm{C}$ for 5 min to stop the reaction and analyzed for total reducing sugars, glucose and final digestion products. Enzyme and substrate blanks were included. The detailed experimental conditions are described in the subsequent figures and tables. The percentage of mutanolysis was calculated using the following equation: saccharification $(\%)=$ reducing sugars formed $(\mathrm{mg})$ x $0.9 \times 100 /$ mutan (mg).

Saccharifications were performed in three replicate experiments and analyses carried out in duplicate. The data given are means of all the measurements. The mean standard error of mutan hydrolysis was $\pm 0.52 \%$, and ranged from \pm 0.02 to 0.83 .

The mutan hydrolytic end products were identified by thinlayer chromatography (TLC). The digests $(4 \mu \mathrm{L})$ were spotted periodically on TLC-plates (aluminium sheets with Silica Gel 60, Merck, Darmstadt, Germany). TLC chromatography was performed according to the method described by Côté and Biely (5) using glucose (Merck, Germany), nigerose and nigerotetraose (Sigma-Aldrich, USA) as sugar standards. $N$-(1Naphthyl)ethylenediamine dihydrochloride reagent was used as a sugar locator (3).

\section{RESULTS AND DISCUSSION}

\section{Optimization of mutanase production}

The starting point of these studies was the choice of an optimal medium for an efficient synthesis of mutanase by the strain of Trichoderma harzianum F-340. Among the four tested culture media supported by $0.5 \%$ mutan, the mineral medium A of Mandels et al. (16) was the most effective with respect to mutanase productivity (Table 1). The enrichment of this medium in peptone proteose $(0.1 \%)$ shortened the cultivation time by three days and increased (over two times) mutanase activity compared to the medium without the addition of peptone (medium C). Other media gave much smaller effects during a shorter period of cultivation (2 days). Also, a simple medium reported by Szczodrak et al. (30) for effective dextranase production was found useless for mutanase synthesis. Hence, culture medium A was used in our further studies. 
During initial experiments, the concentration of mutan in the culture medium was $0.5 \%$. To ensure suitable conditions for mutanase production, we studied its activity at mutan concentrations between $0.1 \%$ and $1.0 \%$. As manifested by the data in Table 2, an over three-fold increase in the mutan amount (from $0.3 \%$ to $1.0 \%$ ) elevated the enzyme activity by only $37 \%$. Consequently, using such a high mutan dose is not economically justified, the more so as this biopolymer is not yet available as a commercial product. Based on Table 2, it was concluded that the $0.3 \%$ mutan concentration giving a relatively high enzyme activity would be an adequate substrate concentration for mutanase production. Also, peptone concentration of $0.05 \%$, an initial medium $\mathrm{pH}$ of 5.3, and medium volume of $150 \mathrm{~mL}$ were adopted as best conditions, yielding, in shaken flask cultures, about 0.59-0.72 units of mutanase per $\mathrm{mL}$ of culture broth, after 4 days of cultivation (Table 2).

Table 2. Culturing factors affecting mutanase production by T. harzianum in Mandels medium $\mathrm{A}^{\mathrm{a}}$ : effect of initial $\mathrm{pH}$, medium quantity, and some medium constituents.

\begin{tabular}{|c|c|c|c|c|}
\hline \multirow[t]{2}{*}{ Serial No. } & \multirow{2}{*}{$\begin{array}{l}\text { Factor } \\
\text { varied }\end{array}$} & \multirow{2}{*}{$\begin{array}{c}\text { Concentration } \\
\%\end{array}$} & \multicolumn{2}{|c|}{ Mutanase activity } \\
\hline & & & $(\mathrm{U} / \mathrm{mL})$ & (U/mg protein) \\
\hline \multirow[t]{4}{*}{1.} & Mutan & 0.1 & 0.265 & 0.911 \\
\hline & & 0.3 & 0.587 & 2.010 \\
\hline & & 0.5 & 0.690 & 2.240 \\
\hline & & 1.0 & 0.804 & 2.481 \\
\hline \multirow[t]{4}{*}{2.} & Peptone ${ }^{\mathrm{c}}$ & 0.025 & 0.568 & 2.186 \\
\hline & & 0.050 & 0.680 & 2.345 \\
\hline & & 0.100 & 0.543 & 1.989 \\
\hline & & 0.200 & 0.135 & 0.298 \\
\hline \multirow[t]{6}{*}{3.} & $\begin{array}{l}\text { Initial } \mathrm{pH} \text { of } \\
\text { the medium }\end{array}$ & & & \\
\hline & 4.0 & & 0.502 & 1.813 \\
\hline & 5.0 & & 0.660 & 2.183 \\
\hline & 5.3 & & 0.700 & 2.450 \\
\hline & 5.5 & & 0.628 & 2.326 \\
\hline & 6.0 & & 0.298 & 1.257 \\
\hline \multirow[t]{5}{*}{4.} & $\begin{array}{l}\text { Volume of optimiz } \\
\text { medium taken (ml }\end{array}$ & & & \\
\hline & 50 & & 0.621 & 1.966 \\
\hline & 100 & & 0.704 & 2.167 \\
\hline & 150 & & 0.724 & 2.471 \\
\hline & 200 & & 0.560 & 1.958 \\
\hline
\end{tabular}

${ }^{\mathrm{a} C o m p o s i t i o n ~ o f ~ t h e ~ m e d i u m ~ w a s ~ t h e ~ s a m e ~ a s ~ t h a t ~ o f ~ t h e ~ o r i g i n a l ~ o n e, ~ e x c e p t ~ f o r ~}$ the factor or its concentration that varied as indicated; ${ }^{b}$ Enzyme activity in culture supernatants was measured after 4 days of submerged cultivation in shaken flask cultures; ${ }^{\mathrm{c} C o n c e n t r a t i o n}$ of mutan was $0.3 \%$; ${ }^{\mathrm{d}}$ Concentration of mutan was $0.3 \%$; dose of peptone was $0.05 \%$; ${ }^{\mathrm{e} C o n c e n t r a t i o n}$ of mutan was $0.3 \%$; dose of peptone was $0.05 \%$; $\mathrm{pH}$ was 5.3 .
The use of conidia as inoculum extends the cultivation time by a stage indispensable to form a physiologically active mycelium. Therefore, an attempt was made to replace conidia of T. harzianum by a suspension of its vegetative mycelium to shorten the cultivation time on the selected medium. The use of $20 \%$ of $72 \mathrm{~h}$ mycelium as inoculum shortened the incubation time by one day, as compared to the use of conidial suspension, maintaining mutanase activity on a slightly higher level (also in the case of specific activity) than that obtained in control runs (Table 3). Similar results with respect to cellulases were reported by Szczodrak (29) using a $48 \mathrm{~h}$ suspension of Trichoderma reesei mycelium. Also, Shukla et al. (27) observed the highest formation of dextranase by Penicillium aculeatum, $P$. purpurogenum, and $P$. funiculosum with the use of an inoculum containing $4 \%$ of $48 \mathrm{~h}$ mycelium.

Also, a comparison was made between production of mutanase by $T$. harzianum when the organism was grown in optimized medium containing various carbohydrates and when mycelial mass was the sole carbon source and inducer of mutanase synthesis. From 16 sugars tested, mutan was the most specific and effective inducer of enzyme synthesis (Table 4). The maximum mutanase activities $(0.7 \mathrm{U} / \mathrm{mL}, 2.5 \mathrm{U} /$ $\mathrm{mg}$ protein) were measured on the third day of cultivation. A slight mutanolytic activity ( 0.01 to 0.03 $\mathrm{U} / \mathrm{mL}$ ) was also found when pullulan, laminarin, alternan, amylose, amylopectin, raffinose, and maltose were carbon sources. Other carbohydrates had no effect on enzyme induction. Raffinose induced mutanase production was also reported by Quivey and Kriger (22) in shaken flask cultures of $T$. harzianum OMZ 779 strain.

It should be noted here that glucans present in the mycelial cell wall are relatively good stimulants of mutanase synthesis by T. harzianum. As shown in Table 4 , the enzyme activity reached a significant value of about $0.07 \mathrm{U} / \mathrm{mL}(0.24 \mathrm{U} / \mathrm{mg}$ protein) with mycelial mass as the substrate in a short period of time (2 days). Thus, this raw material could be considered as a useful, inexpensive and easily available substitute for bacterial mutan. The identification of alternative and inexpensive carbon sources (such as vegetative mycelium) capable of inducing mutanase synthesis is justified, as it would facilitate the enzyme production on a larger scale and at relatively low costs. Therefore, further experiments on intensification of fungal mutanase produced on accessible carbon sources (e.g. waste mycelium coming from biotechnological factories) are now in progress in this laboratory.

Based on the results presented in Tables 1-4, Mandels medium A with initial pH 5.3 and a volume of 
$150 \mathrm{~mL}$, supported by $0.3 \%$ mutan, $0.05 \%$ peptone and $0.1 \%$ Tween 80 , inoculated with $20 \%$ of $72 \mathrm{~h}$ mycelium of T. harzianum and incubated for 3 days at $30^{\circ} \mathrm{C}$, was proven to be the best for mutanase production in shaken flask cultures. Under these conditions, the mutanase yield ranged from 0.59 to $0.72 \mathrm{U} / \mathrm{mL}$ of culture supernate.

Table 3. Effect of the kind and amount of inoculum from $T$. harzianum on mutanase activity in shaken flask cultures ${ }^{\mathrm{a}}$.

\begin{tabular}{ccc}
\hline Inoculum quantity, v/v\% & \multicolumn{2}{c}{ Mutanase activity } \\
\cline { 2 - 3 } & $(\mathrm{U} / \mathrm{mL})$ & $\mathrm{U} / \mathrm{mg}$ protein \\
\hline $1^{\mathrm{b}}$ & 0.698 & 2.350 \\
$1^{\mathrm{c}}$ & 0.177 & 0.926 \\
$2^{\mathrm{c}}$ & 0.276 & 1.359 \\
$5^{\mathrm{c}}$ & 0.500 & 2.145 \\
$10^{\mathrm{c}}$ & 0.583 & 2.233 \\
$20^{\mathrm{c}}$ & 0.716 & 2.557 \\
\hline
\end{tabular}

${ }^{\mathrm{a}}$ Mandels optimized medium A with $0.3 \%$ mutan was used; ${ }^{\mathrm{b}}$ Control inoculated with aqueous suspension of conidia of T. harzianum $\left(2 \times 10^{5} \%\right.$ $\mathrm{mL}$ ); enzyme activity for the control test was determined after 4 days of culture; ${ }^{\circ}$ Experimental tests inoculated with a suspension of vegetative T. harzianum mycelium $(72 \mathrm{~h})$ precultured on Mandels medium with glucose $(0.5 \%)$; enzyme activity was determined after 3 days of culture.
In order to scale up the mutanase production, T. harzianum strain was grown on the optimized medium in $1.8 \mathrm{~L}$ batches in 2.5 $\mathrm{L}$ fermenter under established conditions. Fig. 1 shows a typical culture time course of T. harzianum when the organism was grown in fermenter for 7 days. Mutanase activity was gradually increasing for 5 days, and then slowly declined. The maximum

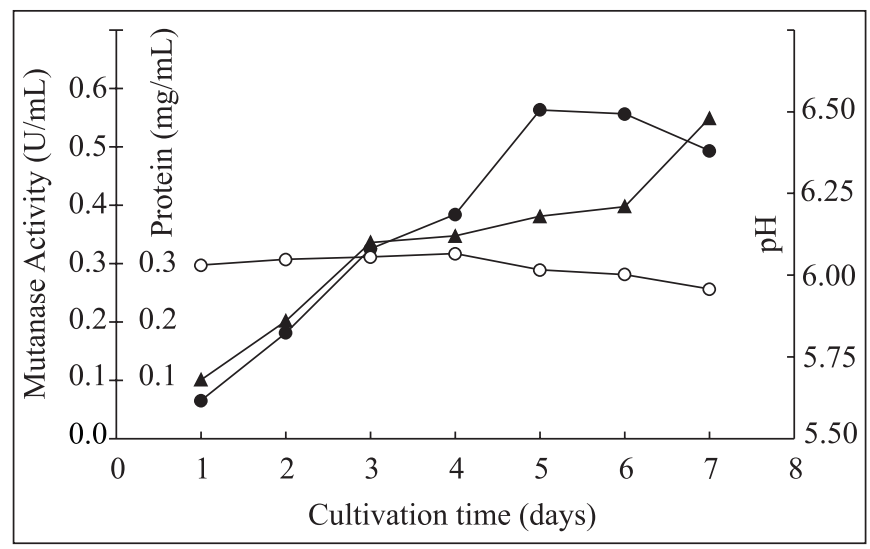

Figure 1. Rates of mutanase $(\bigcirc)$ and protein production $(\mathrm{O})$, and changes in $\mathrm{pH}(\boldsymbol{\Delta})$ during fermenter culture of $T$. harzianum on optimized medium containing mutan as the sole carbon source. Initial medium $\mathrm{pH}$ was 5.3.
Table 4. Effect of carbon source on mutanase production by T. harzianum in shaken flask cultures ${ }^{\mathrm{a}}$.

\begin{tabular}{|c|c|c|c|c|}
\hline \multirow[t]{2}{*}{ Carbon source } & \multirow{2}{*}{$\begin{array}{l}\text { Main linkage(s) } \\
\text { or Constituent }\end{array}$} & \multirow[t]{2}{*}{ Days $^{b}$} & \multicolumn{2}{|c|}{ Mutanase activity } \\
\hline & & & $(\mathrm{U} / \mathrm{mL})$ & (U/mg protein) \\
\hline Mutan $^{c}$ & $\alpha-1,3 ; \alpha-1,6$ & 3 & 0.709 & 2.514 \\
\hline Pullulan & $\alpha-1,6 ; \alpha-1,4$ & 4 & 0.029 & 0.139 \\
\hline Laminarin & $\beta-1,3$ & 4 & 0.026 & 0.078 \\
\hline Alternan & $\alpha-1,3 ; \alpha-1,6$ & 3 & 0.016 & 0.056 \\
\hline Amylose & $\alpha-1,4$ & 3 & 0.020 & 0.044 \\
\hline Amylopectin & $\alpha-1,4 ; \alpha-1,6$ & 3 & 0.013 & 0.035 \\
\hline Raffinose & $\alpha-1,6 ; \alpha, \beta-1,2$ & 4 & 0.014 & 0.086 \\
\hline Maltose & $\alpha-1,4$ & 4 & 0.017 & 0.053 \\
\hline $\begin{array}{l}\text { Wet mycelium }{ }^{\mathrm{d}} \\
\text { (homogenized) }\end{array}$ & $\begin{array}{c}\text { Glucans } \\
\text { in mycelial cell wall: } \\
\beta-1,3 ; \beta-1,6 ; \alpha-1,3\end{array}$ & 2 & 0.063 & 0.237 \\
\hline
\end{tabular}

${ }^{a}$ Mandels optimized medium A with $0.3 \%$ mutan or $1 \%$ other carbon sources was

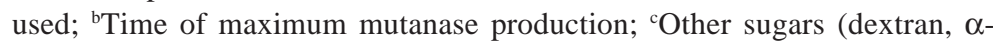
cyclodextrin, trehalose, melibiose, sucrose, fructose, glucose) supported only the growth of the organism, but none or trace activity of mutanase was detected in this set of carbohydrates; ${ }^{\mathrm{d}} \mathrm{A} 72 \mathrm{~h}$ mycelial mass of Aspergillus wentii, precultured on growth medium with glucose (1\%), was used as the sole carbon source. mutanase yield $(0.56 \mathrm{U} / \mathrm{mL}, 2.0 \mathrm{U} / \mathrm{mg}$ protein) and extracellular protein accumulation $(0.32 \mathrm{mg} / \mathrm{mL})$ were monitored on the fifth and fourth days of cultivation, respectively. The $\mathrm{pH}$ of the medium rose (from 5.7 to 6.5) over the whole period of incubation. Consequently, a 5 day period was assumed as the optimum time for the synthesis of mutanase by $T$. harzianum in fermenter cultures.

Application of optimized medium and cultural conditions in shaken flasks and aerated fermenter cultures enabled us to obtain a high mutanase yield (0.6-0.7 U/mL, 2.0-2.5 U/mg protein) in a short period of time (3-5 days). This productivity is at present the best reported in literature. For example, Guggenheim and Haller (9), testing the enzyme production of $T$. harzianum OMZ 779 in fermenter runs, obtained an activity of $0.08 \mathrm{U} / \mathrm{mL}$ after 155 to $165 \mathrm{~h}$. In shaken flask cultures, supplemented with $1 \%$ mutan, mutanase activity would reach its maximum yield of $0.16 \mathrm{U} / \mathrm{mL}$ after $120 \mathrm{~h}$ of incubation. Meanwhile, Quivey and Kriger (22), using the same fungal strain, reached the specific mutanase activity of $0.37 \mathrm{U} / \mathrm{mg}$ protein after 4 days in shaken flask cultures. Also, basing on Streptomyces chartreusis, 
Inoue et al. (10), obtained, after 3 days in shaken flask cultures, the maximum mutanase activity of $0.005 \mathrm{U} / \mathrm{mL}$. In the case of bacterial mutanases, Matsuda et al. (19) achieved enzyme activities of $0.17 \mathrm{U} / \mathrm{mL}$ and $0.039 \mathrm{U} / \mathrm{mg}$ protein in a flask culture of Bacillus circulans, grown for $36 \mathrm{~h}$ on mutan composed mainly of $\alpha-1,3$ glucan, whereas Ebisu et al. (6) after $24 \mathrm{~h}$ in a $10 \mathrm{~L}$ fermenter culture of Flavobacterium obtained an enzyme yield of $0.003 \mathrm{U} / \mathrm{mL}$.

\section{Characteristics of crude mutanase preparation}

Post culture supernatant or cell-free extract of T. harzianum obtained after 5 days of fermenter culture on mutan was used as non-purified mutanase preparation in studies of its enzymic characteristics. As seen in Table 5, the preparation showed a high extracellular mutanase activity and trace activity $(0.1 \%)$ of intracellular enzyme. Besides high mutanolytic activity, the crude enzyme also contained small amounts of accompanying hydrolytic enzymes, such as pullulanase, invertase and chitinase. On the other hand, the mutanase preparation contained practically no dextranase and protease activities. The absence of protease in the culture supernate is very important for successful creation of enzymic preparations for safe oral and caries prophylactic applications. Some of mutanase preparations tested in the past contained large amounts of impurities, which caused certain local side effects in the oral cavity (12).

\section{Enzyme properties}

The crude mutanase preparation (post culture supernate) was stable for one day at room temperature and at $4^{\circ} \mathrm{C}$, and for four days at $-20^{\circ} \mathrm{C}$. The enzyme in crude state was also found highly stable after one treatment freezing and thawing. The lyophilized enzyme preparation was stable under storage conditions for one month at $4^{\circ} \mathrm{C}$, but it lost $36 \%$ of the initial activity after 6 months.

Table 5. Characteristics of the non purified mutanase preparation from T. harzianum.

\begin{tabular}{lcc}
\hline \multirow{2}{*}{ Enzyme } & \multicolumn{2}{c}{ Activity } \\
\cline { 2 - 3 } & $(\mathrm{U} / \mathrm{mL})$ & $(\mathrm{U} / \mathrm{mg}$ protein $)$ \\
\hline Extracellular mutanase $^{\mathrm{a}}$ & 0.5700 & 2.467 \\
Intracellular mutanase $^{\mathrm{b}}$ & 0.0006 & 0.002 \\
Dextranase $^{\mathrm{a}}$ & 0.0000 & 0.000 \\
Pullulanase $^{\mathrm{a}}$ & 0.0240 & 0.104 \\
Invertase $^{\mathrm{a}}$ & 0.0065 & 0.028 \\
Chitinase $^{\mathrm{a}}$ & 0.1690 & 0.732 \\
Protease $^{\mathrm{a}}$ & trace & trace \\
\hline
\end{tabular}

${ }^{\text {aPost }}$ culture supernatant or cell-free extract ${ }^{\mathrm{b}}$ obtained after 5 days fermenter culture of fungus on optimized medium with mutan.
The effects of $\mathrm{pH}$ and temperature on the activity and stability of T. harzianum mutanase are illustrated in Fig. 2. The optimum $\mathrm{pH}$ for the enzyme activity was $\mathrm{pH} 5.5$, and the enzyme was relatively stable in the $\mathrm{pH}$ range of 4.5-6.0. The effect of temperature on mutanase activity was investigated in the range of $20-60^{\circ} \mathrm{C}$. Mutan hydrolysis by the enzyme reached the highest rate at $45^{\circ} \mathrm{C}$. Thermostability studies showed that after $1 \mathrm{~h}$ incubation the enzyme was stable at temperatures of up to $40^{\circ} \mathrm{C}$. At $50^{\circ} \mathrm{C}$ the enzyme lost about $20 \%$ of its maximum mutanolytic activity, which rapidly decreased at temperatures above $50^{\circ} \mathrm{C}$ resulting in a $91 \%$ loss at $60^{\circ} \mathrm{C}$.

The $\mathrm{pH}$ optimum observed is not exactly in agreement with the one reported earlier at $\mathrm{pH} 6.0$ for the T. harzianum OMZ 779 mutanase (9), yet comparable to that obtained for the Microbispora rosea mutanase (4). Correspondingly, bacterial mutanases from B. circulans (19), Flavobacterium (6) and Microbispora rosea (4) have $\mathrm{pH}$ optima similar (5.5) or higher (6.3-6.9) than fungal mutanases, and similar temperature optima
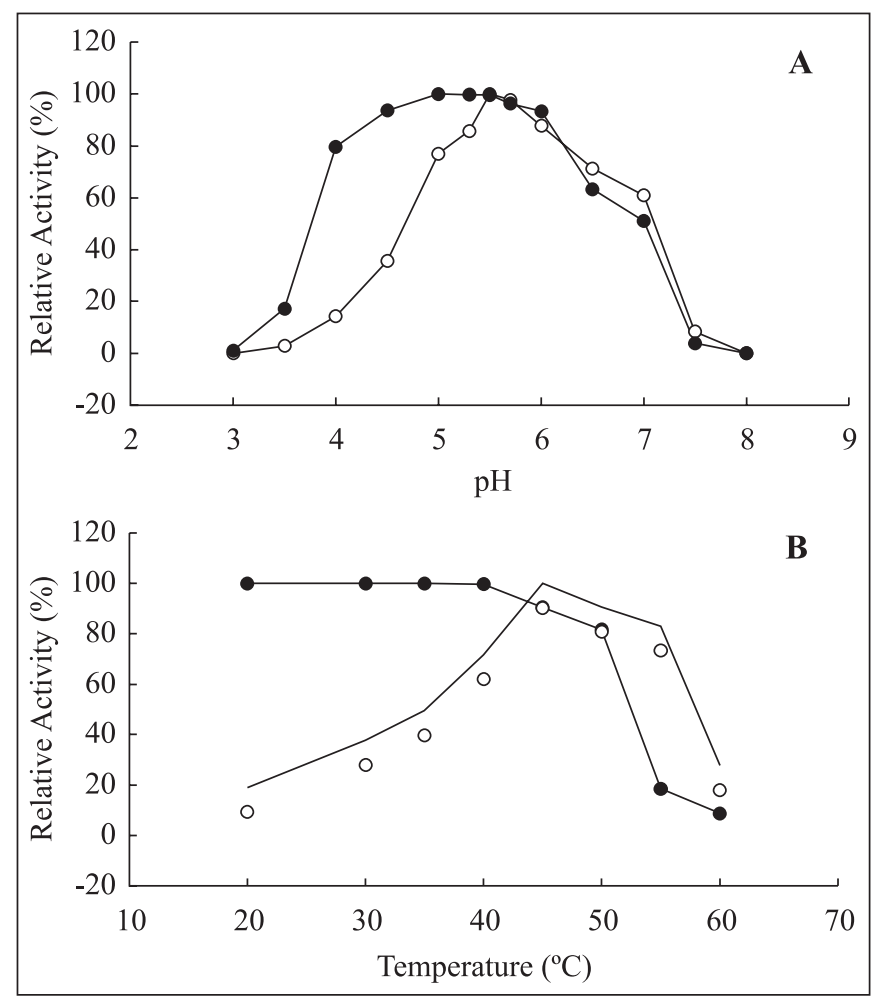

Figure 2. Effects of $\mathrm{pH}(\mathrm{A})$ and temperature (B) on activity (O) and stability (-) of T. harzianum mutanase. (A) $0.2 \mathrm{M}$ McIlvaine buffer of various $\mathrm{pH}$ values was used instead of acetate buffer in the standard assay. (B) The activity was assayed by the standard method except for the reaction temperature that changed as indicated. Other experimental details as described in Materials and Methods. 
$\left(40-50^{\circ} \mathrm{C}\right)$. Although $\mathrm{pH}$ in the oral cavity is around $\mathrm{pH} 6-7$, the slightly acidic $\mathrm{pH}$ profile of the fungal mutanase may be of importance in its application for plaque removal, as low $\mathrm{pH}$ values have been observed locally in the plaque (21).

\section{Hydrolysis of mutan by T. harzianum mutanase}

Hydrolysis of a mixed-linkage streptococcal mutan by lyophilized mutanase preparation was performed under standardized conditions in $50 \mathrm{~mL}$ batches in $100 \mathrm{~mL}$ flasks. The dynamics of mutanolysis and glucose content in hydrolyzates (measured enzymically) during $48 \mathrm{~h}$ are depicted in Fig. 3. After $24 \mathrm{~h}$, the degree of mutan saccharification was $69.2 \%$ and glucose content $88.5 \%$. It is important to notice that after $12 \mathrm{~h}$ of mutanolysis, a relatively high conversion of mutan to soluble digestion products (about 37\%) was attained. However, extension of the hydrolysis time to $48 \mathrm{~h}$ produced only a negligible increase in hydrolysis and glucose yields ( $2.4 \%$ and $0.7 \%$, respectively). Accordingly, a $24 \mathrm{~h}$ period was finally assumed as the optimum time for mutan hydrolysis.

For example, during hydrolysis of insoluble mutan, which was synthesized by glucosyltransferase B derived from the construct of S. milleri, Kopec et al. (13), reached only $15.3 \%$ saccharification of this biopolymer with purified T. harzianum mutanase after $4 \mathrm{~h}$ of incubation at $30^{\circ} \mathrm{C}$. Similar results (hydrolysis yield of up to $20 \%$ after $48-64 \mathrm{~h}$ at $37^{\circ} \mathrm{C}$ ) were obtained for Dextranase 50L (a commercial preparation containing several hydrolytic activities) and glucanhydrolase with mixed (dextranolytic and amylolytic) activity from Lipomyces starkeyi $(17,24)$. Hydrolysis of $S$. sobrinus mutan, composed mainly of $\alpha-1,3$-glucan (99.4\%), by mutanase from Bacillus circulans resulted in $31 \%$ saccharification of this substrate after $10 \mathrm{~h}$ at

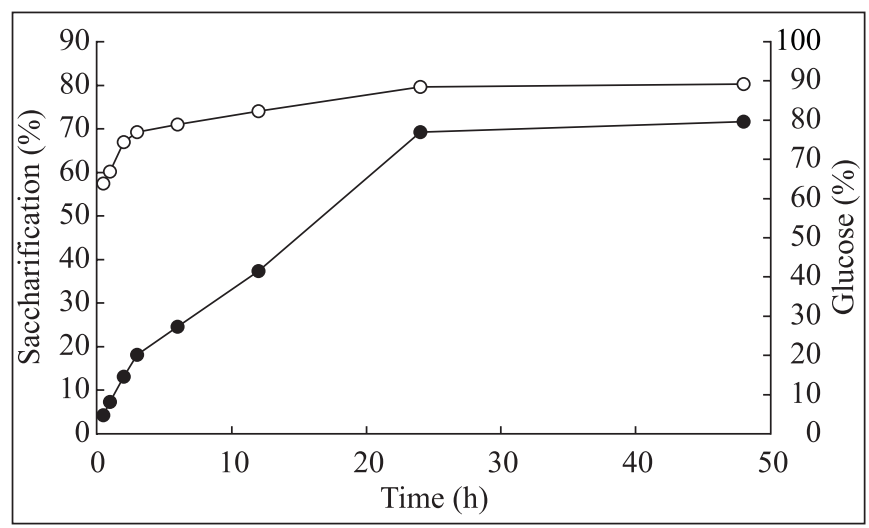

Figure 3. Time course of mutan hydrolysis with T. harzianum mutanase $(\bigcirc)$ and the glucose content in mutan hydrolysates (O). Hydrolysis was conducted in standardized conditions, as described in Materials and Methods. Enzyme concentration: $0.195 \mathrm{U} / \mathrm{mg}$ substrate. Glucose was measured enzymically. $35^{\circ} \mathrm{C}$ (19). After hydrolyzing water-insoluble polyglucans of cariogenic streptococci with Streptomyces mutanase for $60 \mathrm{~min}$ at $55^{\circ} \mathrm{C}$, Inoue et al. (10) reported a degradation in the range from 2.0 to $4.9 \%$, respectively. Also Ebisu et al. (6) assayed the susceptibilities of insoluble polysaccharides produced by oral streptococci to bacterial mutanase. In the case of the Flavobacterium enzyme, the above mentioned authors obtained about $10.1 \%$ saccharification after $24 \mathrm{~h}$ of mutan hydrolysis at $37^{\circ} \mathrm{C}$, while at the same time about half of glucan was solubilized. The degradation of insoluble plaque polysaccharides by T. harzianum OMZ 779 mutanase attained about 50\% saccharification after an overnight incubation at $40^{\circ} \mathrm{C}(9)$. A high degree of mutan degradation (31.5\%) after $30 \mathrm{~min}$ of enzymatic reaction at $37^{\circ} \mathrm{C}$ was also reported for highly purified recombinant mutanase (31).

The action pattern of $T$. harzianum mutanase towards mutan was examined by comparing the rate of glucose production to that of reducing sugar production at different times. This method is often used to confirm the exo or endo mechanism of the enzyme action (33). Incubations of mutan with the enzyme resulted in an almost 1:1 correlation between the production of reducing sugars and glucose (Fig. 4). Therefore, glucose accounts for almost all of the reducing sugar and is the major hydrolysis product of the enzyme. A relatively constant (reducing sugars/glucose) ratio obtained over the whole hydrolysis period indicates unequivocally that the tested mutanase exhibits an exo type of action, with glucose as the main early and final hydrolytic product. Also Ait-Lahsen et al. (1) observed an identical mode of action for an antifungal exo$\alpha-1,3$-glucanase isolated from the strain of biocontrol fungus $T$. harzianum CECT 2413.

Some mutanases split $\alpha-1,3$ linkages in insoluble glucans of streptococcal origin by endo-type degradation. For example,

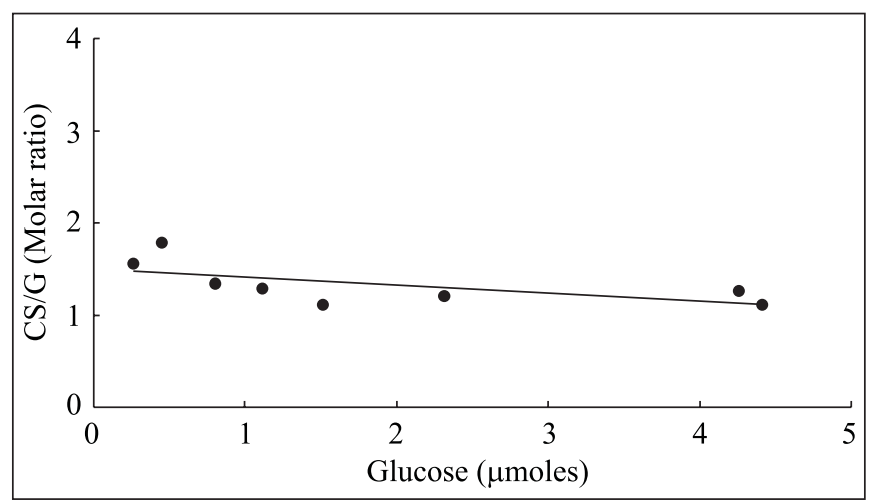

Figure 4. Mechanism of action of T. harzianum mutanase. Hydrolysis conditions described in Materials and Methods. CS, total carbohydrate solubilized (reducing sugars); G, glucose (analyzed enzymically). 
Guggenheim and Haller (9) have found purified mutanases from the strain of T. harzianum OMZ 779 to operate by a completely random attack, that is, by an endo mechanism. Similar results were reported for Flavobacterium $\alpha$-1,3-glucanase hydrolyzing insoluble, sticky glucan of S. mutans (6). The action pattern of mutanase separated from a commercial preparation of Dextranase $\mathrm{S}$ revealed the enzyme to be composed of an exoand endo- $\alpha-(1 \rightarrow 3)$ glucanase $(8)$.

The soluble end products of mutan hydrolysis were identified by TLC chromatography. Samples were withdrawn for various periods of up to $48 \mathrm{~h}$. As shown by TLC analysis (Fig. 5), glucose was present in hydrolyzates over the whole hydrolysis period as the main initial and final hydrolytic product. Its content increased gradually over the whole digestion cycle as a result of degradation of intermediate higher molecular weight oligomers (compare the size and intensity of glucose spots visible on TLC chromatogram). The heat inactivated enzyme preparation contained end products free of any reducing sugar. After $48 \mathrm{~h}$ of mutan hydrolysis, the amount of glucose constituted $89 \%$ of the total pool of hydrolytic products (see Fig. 3). These results confirm the issue discussed earlier that the tested mutan-degrading mutanase operates in an exo fashion.

Other researchers $(1,9,22)$ also detected glucose as the major product of mutan hydrolysis with mutanase derived from various strains of T. harzianum. Glucose and isomaltose or glucose and fructose were the main degradation products from mutan after incubation with Penicillium and T. harzianum mutanases, respectively $(8,13)$. Other results were obtained by Ebisu et al. (6), and Matsuda et al. (19). On hydrolyzing mutan with bacterial mutanases, hydrolyzates contained dimers, trimers and tetramers of glucose but no glucose as the primary soluble products of glucan digestion.

Summarizing, the data presented here imply that the tested T. harzianum strain potentially represents a new and highly effective source of extracellular mutanase. The enzymic productivity of this fungus, obtained for mutan in shaken flasks and fermenter cultures under standardized conditions, was much higher than the best reported so far. Moreover, the vegetative mycelium may be used as a substitute for mutan to considerably reduce the costs of mutanase production. The mutanase preparation obtained from this strain was relatively stable during storage, free of dextranase and protease activities, and showed a high hydrolytic potential with an exolytic mode of action on insoluble mutan of streptococcal origin. Therefore, the enzyme could be applied as an active ingredient in dental gel, chewing gum, toothpaste, or mouthwash to prevent the accumulation of mutan in dental plaque and as a useful supplement to mechanical cleaning of teeth and dentures. Thus, further experiments are currently in progress to estimate the operational stabilities and some kinetic properties of mutanase administered in dentifrice preparations.

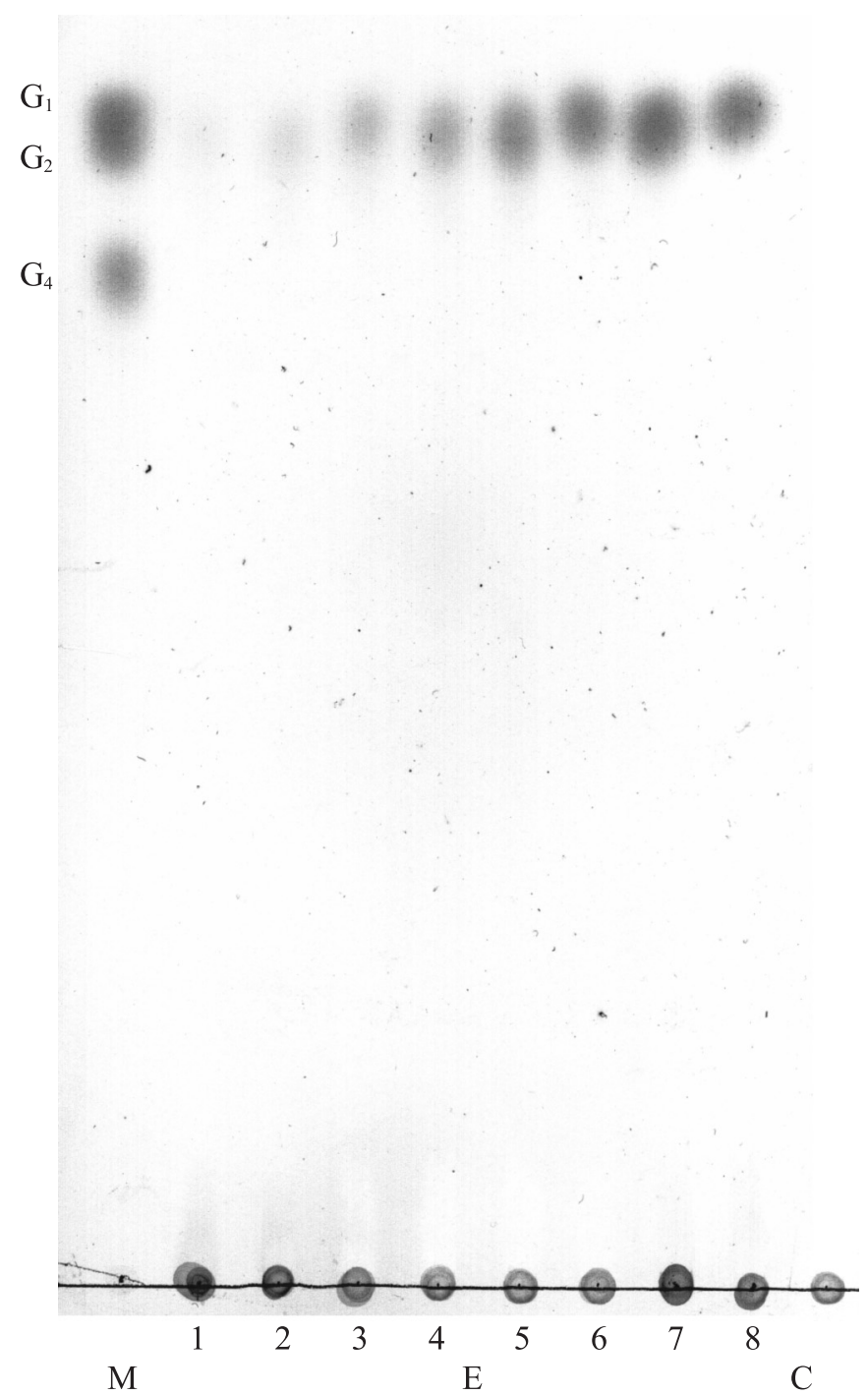

Figure 5. TLC chromatogram of hydrolysis products of mutan obtained with mutanase preparation from $T$. harzianum. Hydrolysis conditions as in Materials and Methods. The samples applied were: $\mathrm{M}$ - marker, $\mathrm{G}_{1}-$ glucose, $\mathrm{G}_{2}$ - nigerose, $\mathrm{G}_{4}$-nigerotetraose; $\mathrm{E}$ - sample from enzymic digestion of mutan at different periods of incubation: 1 (30 min), 2 (1 h), 3 (2 h), 4 (3 h), 5 (6 h), 6 (12 h), 7 (24 h), 8 (48 h); C - heat-inactivated enzyme. Four microliters of each sample were spotted on the TLC plate. The locator was naphthylethylenediamine dihydrochloride reagent. See the text for the other experimental details.

\section{ACKNOWLEDGMENTS}

This work was financially supported by the BW/BS/BiNoZ/ UMCS Research Programs. 


\section{RESUMO}

\section{Produção e utilização da mutanase de Trichoderma harzianum para a degradação efetiva dos mutans estreptocócicos de estreptococos mutans}

Os parâmetros básicos que afetam a produção da mutanase por Trichoderma harzianum F-340 em frascos agitados e em fermentadores foram estabelecidos. O melhor meio para produção da enzima foi o meio Mandels com $\mathrm{pH}$ inicial de 5,3, suplementado com $0,3 \%$ de mutana e $0,05 \%$ de peptona e inoculado com $20 \%$ de um micélio de $72 \mathrm{~h}$. Demonstrou-se que a massa micelial, usada como única fonte de carbono no meio de cultura, induziu a síntese de mutanase, podendo ser empregada como um substituto barato e de fácil obtenção de mutana bacteriana. Empregando-se condições otimizadas de cultura, foi possível obter um alto rendimento de produção de mutanase (0,6-0,7 U/mL, 2,0-2,5 U/mg de proteína) em pouco tempo (3-5 dias), ultrapassando os melhores resultados relatados na literatura. A enzima bruta foi estável em pH de 4,5 até 6,0 e em temperatura até $40^{\circ} \mathrm{C}$. A atividade máxima foi obtida a $45^{\circ} \mathrm{C} \mathrm{e} \mathrm{pH}$ 5,5. A mutanase obtida deste fungo foi bastante estável durante a seu armazenamento e apresentou um levado potencial hidrolítico sobre as ligações mistas $(\alpha-1,3, \alpha-1,6)$ da mutana estreptocócica insolúvel em água (a taxa de hidrólise em 24 horas foi 69\%). Os produtos resultantes da reação enzimática durante a hidrólise indicaram que a mutanase possuía uma ação tipo exo sobre a mutana. A análise cromatográfica em camada delgada mostrou que o principal produto resultante da ação da mutanase sobre a mutana era glicose. O potencial de aplicação de mutanase na estomatologia é discutido.

Palavras-chave: Trichoderma harzianum, mutanase, mutana

\section{REFERENCES}

1. Ait-Lahsen, H.; Soler, A.; Rey, M.; de la Cruz, J.; Monte, E.; Llobell, A. An antifungal exo- $\alpha-1,3$-glucanase (AGN13.1) from the biocontrol fungus Trichoderma harzianum. Appl. Environ. Microbiol., 67, 58335839, 2001.

2. Alef, K.; Nannipieri, P. Chitinase activity. In: Alef, K.; Nannipieri, P. (eds.). Methods in Applied Soil Microbiology and Biochemistry. Academic Press Ltd, London, 1995, p.360-361.

3. Bounias, M. $N$-(Naphthyl)ethylenediamine dihydrochloride as a new reagent for nanomole quantification of sugars on thin-layer plates by a mathematical calibration process. Anal. Biochem., 106, 291295, 1980.

4. Chung, J. Characterization of mutanase produced by Microbispora rosea. J. Dent. Res., 77, 1998, p.1322.

5. Côté, G.; Biely, P. Enzymically produced cyclic $\alpha-1,3$-linked and $\alpha$ 1,6-linked oligosaccharides of D-glucose. Eur. J. Biochem., 226, 641-648, 1994.

6. Ebisu, S.; Kato, K.; Kotani, S.; Misaki, A. Isolation and purification of Flavobacterium $\alpha$-1,3-glucanase-hydrolyzing, insoluble, sticky glucan of Streptococcus mutans. J. Bacteriol., 124, 1489-1501, 1975.

7. Fogarty, W.M.; Griffin, P.J. Production and purification of the metalloprotease of Bacillus polymyxa. Appl. Microbiol., 26, 185190, 1973.

8. Guggenheim, B. Enzymatic hydrolysis and structure of water-insoluble glucan produced by glucosyltransferases from a strain of Streptococcus mutans. Helv. Odont. Acta., 14 (Suppl. V), 89-108, 1970.

9. Guggenheim, B.; Haller, R. Purification and properties of an $\alpha$ $(1 \rightarrow 3)$ glucanohydrolase from Trichoderma harzianum. J. Dent Res., 51, 394-402, 1972.

10. Inoue, M.; Egami, T.; Yokogawa, K.; Kotani, H.; Morioka, T. Isolation, identification and some cultural conditions of Streptomyces species that produce water-insoluble polyglucan hydrolase. Agr. Biol. Chem., 39, 1391-1400, 1975.

11. Inoue, M.; Yakushiji, T.; Mizuno, J.; Yamamoto, Y.; Tanii, S. Inhibition of dental plaque formation by mouthwash containing an endo- $\alpha-1,3$ glucanase. Clin. Prevent. Dent., 12, 10-14, 1990.

12. Kelstrup, J.; Holm-Pedersen, P.; Poulsen, S. Reduction of the formation of dental plaque and gingivitis in humans by crude mutanase. Scand. J. Dent. Res., 86, 93-102, 1978.

13. Kopec, L.K.; Vacca-Smith, A.M.; Bowen, W.H. Structural aspects of glucans formed in solution and on the surface of hydroxyapatite. Glycobiology, 7, 927-934, 1997.

14. Lamont, R.J.; Jenkinson, H.F. Adhesion as an ecological determinant in the oral cavity. In: Kuramitsu, H.K.; Ellen, R.P. (eds). Oral Bacterial Ecology: The Molecular Basis. Horizon Scientific Press, Wymondham, Norfolk, UK, 2000, p.131-168.

15. Lloyd, J.B.; Whelan, W.J. An improved method for enzymic determination of glucose in the presence of maltose. Anal. Biochem. 30, 467-470, 1969.

16. Mandels, M.; Parrish, F.W.; Reese, E.T. Sophorose as an inducer of cellulase in Trichoderma viride. J. Bacteriol., 83, 400-408, 1962.

17. Marotta, M.; Martino, A.; De Rosa, A.; Farina, E.; Carteni, M.; De Rosa, M. Degradation of dental plaque glucans and prevention of glucan formation using commercial enzymes. Proc. Biochem., 38, 101-108, 2002.

18. Marsh, P.D.; Bradshaw, D.J. Dental plaque as a biofilm. J. Ind. Microbiol., 15, 169-175, 1995.

19. Matsuda, S.; Kawanami, Y.; Takeda, H.; Ooi, T.; Kinoshita, S. Purification and properties of mutanase from Bacillus circulans. J. Ferment. Bioeng., 83, 593-595, 1997.

20. Nelson, N. A photometric adaptation of the Somogyi method for the determination of glucose. J. Biol. Chem., 153, 375-380, 1944.

21. Oppermann, R.V. Effect of chlorhexidine on acidogenicity of dental plaque in vivo. Scand. J. Dent. Res., 87, 302-308, 1979.

22. Quivey, R.G.; Kriger, P.S. Raffinose-induced mutanase production from Trichoderma harzianum. FEMS Microbiol. Lett., 112, 307312, 1993.

23. Rogalski, J.; Szczodrak, J.; Glowiak, J.; Pleszczyńska, M.; Szczodrak, Z.; Wiater, A. Purification and immobilization of dextranase. Acta Biotechnol., 18, 63-75, 1998.

24. Ryu, S.J.; Kim, D.; Ryu, H.J.; Chiba, S.; Kimura, A.; Day, D.F. Purification and partial characterization of a novel glucanhydrolase from Lipomyces starkeyi KSM 22 and its use for inhibition of insoluble glucan formation. Biosci. Biotechnol. Biochem., 64, $223-$ 228, 2000.

25. Saunders, P.R.; Siu, R.G.H.; Genest, R.N. A cellulolytic enzyme preparation from Myrothecium veerrucaria. J. Biol. Chem., 174, 697-703, 1948.

26. Schacterle, G.R.; Pollack, R.L. A simplified method for the quantitative assay of small amounts of protein in biologic material. Anal. Biochem., 51, 654-655, 1973.

27. Shukla, G.L.; Madhu; Prabhu, K.A. Study of some parameters for the production of dextranase by Penicillium aculeatum. Enzyme Microb. Technol., 11, 533-536, 1989.

28. Somogyi, M. A new reagent for the determination of sugars. J. Biol. Chem., 160, 61-68. 1945. 
A. Wiater et al.

29. Szczodrak, J. Production of cellulases and xylanase by Trichoderma reesei F-522 on pretreated wheat straw. Acta Biotechnol., 8, 509$515,1988$.

30. Szczodrak, J.; Pleszczyń ska, M.; Fiedurek, J. Penicillium notatum 1 a new source of dextranase. J. Ind. Microbiol., 13, 315-320, 1994.

31. Tsuchiya, R.; Fuglsang, C.C.; Johansen, C.; Aaslyng, D. Effect of recombinant mutanase and recombinant dextranase on plaque removal. J. Dent. Res., 77 (Sp. Iss. B), 2713, 1998.

32. Tsumori, H.; Kuramitsu, H. The role of the Streptococcus mutans glucosyltransferases in the sucrose-dependent attachment to smooth surfaces: essential role of the GtfC enzyme. Oral Microbiol. Immunol., 12, 274-280, 1997.

33. Tung, K.K.; Nordin, J.H. Determination of the action patterns of glycanases. Anal. Biochem., 29, 84-90, 1969.

34. Wiater, A.; Choma, A.; Szczodrak, J. Insoluble glucans synthesized by cariogenic streptococci: a structural study. J. Basic Microbiol., 39, 265-273, 1999.

35. Wiater, A.; Szczodrak, J.; Rogalski, J. Hydrolysis of mutan and prevention of its formation in streptococcal films by fungal $\alpha$-Dglucanases. Proc. Biochem., 39, 1481-1489, 2004. 